\title{
Hakikat Pembukaan Dalam UUD 1945
}

\section{Ni’matul Huda}

\section{Abstract}

The spirit of the 1945 constitution preamble is the fundamental principle of Indonesia. Whether or not the 1945 Constitution is changed, it relates to a political matter, so that a prohibition to change the preamble shoeld be included in the constitution.

\section{Kesepakatan MPR Tahun 1999}

Dalam Sidang Tahunan Majelis Permusyawaratan Rakyat tahun 1999 disepakati untuk tidak mengubah Pembukaan UUD 1945 karena hal itu dipandang sudah final. Kesepakatan untuk tidak mengubah Pembukaan UUD 1945 dulu pemah dilakukan oleh Majelis Permusyawaratan Rakyat Sementara (MPRS). Penegasan tersebut ditegaskan dalam Ketetapan MPRS No. XX/MPRS/1966. Dalam lampiran Ketetapan MPRS №. XXMPRS/1966 tentang Memorandum DPR-GR Mengenai Sumber Tertib Hukum RI dan Tata Urutan Peraturan Perundang-undangan RI, Bagian l, No. 3 sub c., dinyatakan bahwa:

"Pembukaan UUD 1945 sebagai Pernyataan Kemerdekaan yang terperinci yang mengandung cita-cita luhur dari Proklamasi 17 Agustus 1945 dan yang memuat Pancasila sebagai Dasar Negara merupakan satu rangkaian dengan Proklamasi 17 Agustus 1945 dan oleh karena itu tidak dapat dirubah oleh siapapun juga, termasuk MPR hasil Pemilu, yang berdasarkan Pasal 3 dan Pasal 37 UUD berwenang menetapkan dan merubah UUD karena merubah isi Pembukaan berarti pembubaran Negara. Dalam kedudukannya yang demikian tadi Pembukaan UUD 1945 merupakan dasar dan sumber hukum dari batang tubuhnya."

Pernyataan tersebut kemudian ditegaskan kembali dalam Ketetapan MPR No. III/MPR/1983 jo Ketetapan MPR No. III/MPR/ 1988 (kedua Ketetapan MPR tersebut rumusannya sama). Adapun pandangan atau dasar pikiran yang melatar belakangi ialah karena Pembukaan UUD 1945:

a. mengandung cita-cita luhur Proklamasi Kemerdekaan 1945;

b. memuat Pancasila sebagai Dasar Negara;

c. merupakan satu kesatuan dengan Proklamasi Kemerdekaan 17 Agustus 1945;

d. merubah isi Pembukaan UUD 1945 berarti membubarkan Negara Proklamasi Kemerdekaan Republik Indonesia.

Penegasan ini ada kemiripannya dengan pendapat Notonagoro pada Seminar Pancasila tahun 1955 yang mengatakan, Pembukaan UUD 
1945 itu merupakan pokok kaidah fundamental Negara Republik Indonesia dan mempunyai kedudukan tetap terlekat kepada kelangsungan Negara Republik Indonesia atas Proklamasi Kemerdekaan tanggal 17 Agustus 1945. Oleh karena itu, tidak dapat diubah dengan jalan hukum.'

Menurut M. Tolchah Mansoer, ${ }^{2}$ merubah Pancasila berarti mengubah Negara Republik Pancasila dan melenyapkan Pancasila berarti membubarkan Negara Republik Pancasila yang dilahirkan berdasarkan Proklamasi 17 Agustus 1945. Berdasarkan Ketetapan MPRS No. XX/MPRS/1966 tersebut Pembukaan UUD 1945 pada hakikatnya adalah bagian yang paling essensiil UUD 1945.

Timbul pertanyaan, sampai seberapa jauhkah kekuatan hukum pendapat MPR tersebut? Dalam UUD 1945, baik dalam batang tubuh maupun dalam penjelasannya tidak dijumpai ketentuan yang melarang diubahnya Pembukaan UUD. Hukum Tata Negara dan Hukum Konstitusi Indonesia tidak memberikan jawaban terhadap masalah tersebut. Sekalipun demikian, untuk menjawab pertanyaan serta meninjau masalah tidak dapat diubahnya Pembukaan UUD 1945 ditinjau dari landasan hukum, ada beberapa hal yang dapat dipergunakan sebagai bahan pembahasan, yakni:

1. tentang tata urutan peraturan perundangundangan di negara Republik Indonesia;

2. tentang kedudukan ketentuan yang berbunyi, bahwa "UUD 1945 terdiri dari Pembukaan dan Batang Tubuh";

3. tentang kedudukan Ketetapan MPRS yang berisi ketentuan yang berbunyi "Pembukaan UUD 1945 tidak dapat diubah oleh siapapun, termasuk MPR hasil pemilu".

Pertama, Ketetapan MPR sebagai satu bentuk peraturan perundang-undangan tidak diatur secara jelas dalam Undang-Undang Dasar. Ketetapan MPR/S lahir di tahun 1960an dan terus berjalan hingga munculnya kesepakatan MPR untuk menghapuskan sumber hukum Ketatapan MPR melalui Ketetapan MPR No. 1/MPR/2003 tentang Peninjauan Terhadap Materi dan Status Hukum Ketetapan MPRS dan Ketetapan MPR RI Tahun 1960 Sampai Dengan Tahun 2002.

Memang UUD 1945 tidak menyebut sumber hukum tersebut tetapi karena Ketetapan MPR/S sudah berjalan dalam praktek ketatanegaraan sehingga telah menjadi konvensi. Mengenai bentuk peraturan yang bernama UUD dengan jelas disebut dalam Pasal 3 UUD 1945. Sedangkan sumber hukum Ketetapan MPR diambil dari penafsiran terhadap bunyi Pasal 3 UUD 1945, bahwa MPR menetapkan Garis-garis Besar Haluan Negara (GBHN).

Seperti diketahui, pada asasnya UUD hanya ditetapkan satu kali, kecuali apabila ada alasan-alasan yang kuat. Apabila undangundang dasar atau konstitusi telah ditetapkan, maka dia berkedudukan sebagai fundamental law dalam negara. Ini berarti, bahwa peraturan perundang-undangan yang lain harus sesuai dan tidak bertentangan dengan undangundang dasar. Oleh karena itu adalah tepat ditempatkannya Ketetapan MPR di bawah UUD,

${ }^{1}$ Soejadi, Pancasila Sebagai Sumber Tertib Hukum Indonesia, Lukman Offset, Yogyakarta, 1999, hlm. 106.

${ }^{2}$ Moh. Tolchah Mansoer, Teks Resmi Dan Beberapa Soal Tentang UUD 1945, (Alumni, Bandung, 1983), hlm. 80. 
sebagaimana diatur dalam Ketetapan MPRS No. XXMPRS/1966 yang kemudian telah dicabut oleh Ketetapan MPR No. III/MPR/2000 tentang Sumber Hukum dan Tata Urutan Peraturan Perundang-undangan, ${ }^{3}$ Akan tetapi belakangan eksistensi sumber hukum Ketetapan MPR banyak dipertanyakan karena berubahnya susunan dan kedudukan MPR dalam Pasal 1 ayat (2) UUD 1945, dan tidak jarang dalam praktek muatan materi Ketetapan MPR bertentangan dengan UUD 1945 atau bertindak seolah-olah sejajar dengan UUD itu sendiri. ${ }^{4}$

Salah satu hasil Sidang Tahunan MPR 2002 yang relevan dengan masalah Ketetapan MPR tersebut adalah diubahnya bunyi Aturan Tambahan UUD 1945. Dalam Pasal I ditegaskan "MPR ditugasi untuk melakukan peninjauan terhadap materi dan status hukum Ketetapan MPRS dan Ketetapan MPR untuk diambil putusan pada Sidang MPR 2003"'. Dalam Sidang Tahunan MPR Tahun 2003 telah dikeluarkan Ketetapan MPR No. I/MPR/2003 tentang Peninjauan Terhadap Materi dan Status Hukum Ketetapan MPRS dan Ketetapan MPR RI Tahun 1960 Sampai Dengan Tahun 2002, yang hasilnya dikelompokkan sebagai berikut:

(1) Yang dicabut dan dinyatakan tidak berlaku;

(2) Yang dinyatakan tetap berlaku dengan ketentuan masing-masing sebagai berikut:

a. Ketetapan MPRS No. XXV/MPRS/1966 tentang Pembubaran Partai Komunis Indonesia, Pernyataan Sebagai Organisasi Terlarang di Seluruh
Wilayah Negara RI Bagi Partai Komunis Indonesia dan Larangan Setiap Kegiatan Untuk Menyebarkan atau Mengembangkan Faham atau Ajaran Komunis/Marxisme-Leninisme, dinyatakan tetap berlaku dengan ketentuan seluruh ketentuan dalam Ketetapan MPRS No. XXV/MPRS/1966 ini, kedepan diberlakukan dengan berkeadilan dan menghormati hukum, prinsip demokrasi dan hak asasi manusia.

b. Ketetapan MPR No. XVI/MPR/1998 tentang Politik Ekonomi Dalam Rangka Demokrasi Ekonomi, dinyatakan tetap berlaku dengan ketentuan Pemerintah berkewajiban mendorong keberpihakan politik ekonomi yang lebih memberikan kesempatan dukungan dan pengembangan ekonomi, usaha kecil menengah, dan koperasi sebagai pilar ekonomi dalam membangkitkan terlaksananya pembangunan nasional dalam rangka demokrasi ekonomi sesuai hakikat Pasal 33 UUD Negara Republik Indonesia Tahun 1945.

c. Ketetapan MPR No. V/MPR/1999 tentang Penentuan Pendapat di Timor Timur, tetap berlaku sampai dengan terlaksananya ketentuan dalam Pasal 5 dan Pasal 6 Ketetapan MPR No. V/MPR/1999.

(3) Yang tetap berlaku sampai dengan terbentuknya pemerintahan hasil Pemilu

${ }^{3}$ Sumber Hukum dan Tata Urutan Peraturan Perundang-undangan sekarang mengacu pada UU No. 10 Tahun 2004 tentang Pembentukan Peraturan Perundang-undangan. 2004.

${ }^{4}$ Ketetapan MPR sudah hilang dari tata urutan peraturan perundang-undangan melalui UU No. 10 Tahun 
tahun 2004.

(4) Yang tetap berlaku sampai dengan terbentuknya undang-undang.

(5) Ketetapan MPR tentang Peraturan Tata Tertib MPR yang masih berlaku sampai dengan ditetapkannya Peraturan tata Tertib yang baru oleh MPR hasil Pemilu tahun 2004.

(6) Yang tidak perlu dilakukan tindakan hukum lebih lanjut, baik karena bersifat einmalig (final), telah dicabut, maupun telah selesai dilaksanakan.

Kedua, mengenai kedudukan ketentuan yang berbunyi: "UUD 1945 terdiri dari Pembukaan dan batang tubuhnya." Apabila kita pelajari sejarah pembentukan UUD 1945, kita akan menemukan kenyataan bahwa Pembukaan UUD 1945 berasal dari Piagam Jakarta yang disusun dan dirumuskan oleh Panitia Sembilan. Piagam Jakarta ini mempunyai kedudukan yang kuat, karena disusun dan dirumuskan oleh tokoh-tokoh pergerakan kebangsaan yang mewakili golongan-golongan yang terdapat dalam masyarakat. Apa yang tercantum dalam Piagam Jakarta merupakan gentlement agreement - istilah yang dipergunakan oleh Dr. Soekiman - dari wakilwakil bangsa Indonesia. Rancangan Pembukaan tersebut disusun dan dirumuskan mendahului penyusunan Rancangan UUD.

Oleh karena itu ketentuan dalam Ketetapan MPRS No. XX/MPRS/1966 yang menegaskan bahwa Undang-Undang Dasar 1945 terdiri dari pembukaan dan batang tubuhnya telah menimbulkan dua masalah, yaitu:

1. tentang kedudukan Ketetapan MPRS itu sendiri, dan

2. dinyatakannya Pembukaan sebagai bagian dari UUD 1945.

$\mathrm{Di}$ atas sudah dikemukakan bahwa Ketetapan MPR adalah bentuk peraturan perundang-undangan yang kedudukan dan derajatnya berada di bawah UUD. Oleh karena itu menjadi pertanyaan, apakah Ketetapan MPRS yang berisi ketentuan seperti diuraikan di atas masih dapat dipertahankan?

Menurut Sri Soemantri, ${ }^{5}$ MPRS melalui ketetapannya tidak berwenang untuk berbuat demikian. Dengan dinyatakannya "Pembukaan sebagai bagian dari UUD 1945" MPRS telah menetapkan Pembukaan setingkat dengan UUD, yang dinamakan batang tubuh. Hal ini mempunyai konsekuensi bahwa Pembukaan juga akan termasuk dalam wewenang MPR sebagaimana diatur dalam Pasal 37 UUD 1945, yakni dapat diubah oleh MPR.

Ketiga, masalah "tidak dapat diubahnya Pembukaan UUD 1945 oleh siapapun termasuk MPR hasil pemilu". Dapatkah dibenarkan MPRS membuat ketetapan seperti itu? Ditinjau dari sudut hukum, setiap Ketetapan MPRS atau Ketetapan MPR apapun isinya selalu dapat diubah atau dinyatakan tidak berlaku oleh KetetapanMPR yang lain. Hal ini dikarenakan Ketetapan MPR adalah suatu bentuk peraturan perundangundangan hasil MPR, bukan dalam kedudukannya sebagai Konstituante atau Sidang Pembentukan UUD.

Dari uraian di atas dapat disimpulkan bahwa dapat diubah atau tidaknya Pembukaan UUD 1945 sangat terkait dengan masalah politik, masalah dapat diubah atau tidaknya Pembukaan tidak dapat diatur dalam

${ }^{5}$ Sri Soemantri M, Prosedur dan Sistem Perubahan Konstitusi, (Alumni, Bandung, 1987), hlm. 
peraturan perundang-undangan yang lain, termasuk Ketetapan MPR. Dengan lain perkataan hal itu harus diatur dalam UUD. ${ }^{6}$

Salah satu hasil perubahan UUD 1945 yakni Aturan Tambahan Pasal II menegaskan bahwa UUD Negara Republik Indonesia Tahun 1945 terdiri atas Pembukaan dan Pasalpasal. Kemudian dalam Pasal 37 ditegaskan, bahwa yang dapat diubah adalah pasal-pasal Undang-Undang Dasar, dan yang tidak dapat diubah adalah bentuk Negara Kesatuan Republik Indonesia. Penegasan ini mengukuhkan kesepakatan anggota MPR untuk tidak menjadikan Pembukaan UUD 1945 sebagai obyek perubahan, dan yang dapat diubah adalah pasal-pasal UUD.

Menurut pengamatan ASS Tambunan,? meskipun MPR sudah sepakat untuk tidak merubah (mempertahankan) Pembukaan UUD 1945 tetapi dalam kenyataannya pasalpasal yang merupakan terjemahan dari Pembukaan dirubah juga. Perubahanperubahan yang terjadi secara terang. terangan bertabrakan atau menyimpang dari Pembukaan. Berarti yang dimaksud dengan mempertahankan adalah dalam arti harfiah saja. Lebih lanjut Tambunan menyatakan, bahwa Pembukaan merupakan suatu bagian dari UUD yang tertinggi tingkatannya, artinya bahwa preambule mendasari sistem konstitusi dan mengikat sistem kenegaraan. Dengan demikian, tingkatan Pembukaan UUD 1945 adalah di atas Batang Tubuh dan Penjelasannya. Hal-hal yang terdapat dalam Batang Tubuh dan Penjelasan UUD 1945 tidak boleh terlepas dari Pembukaan. Sistem konstitusi dn struktur bangunan negara Republik Indonesia dibangun di atas landasan Pembukaan UUD 1945. Dalam Pembukaan UUD 1945 terkandung pokok-pokok pikiran yang menguasai hukum dasar yang tertulis maupun yang tidak tertulis. Oleh karenanya perlu diketahui pokok-pokok pikiran apa saja yang terkandung dalam Pembukaan UUD 1945.

\section{Pokok-pokok Pikiran Pembukaan UUD 1945}

Pembukaan UUD 1945 merupakan satu rangkàian kesatuan yang tidak dapat dipisahkan dengan Proklamasi Kemerdekaan Indonesia 17 Agustus 1945. Proklamasi Kemerdekaan Indonesia adalah merupakan perumusan daripada cita-cita bangsa Indonesia yang terkandung dalam hati sanubarinya, suatu cita-cita moral yang hendak dicapai oleh bangsa Indonesia baik dalam lingkungan bangsa Indonesia sendiri maupun dalam pergaulan bangsa-bangsa di dunia. Di dalamnya pun telah terlukis pandangan hidup dan tujuan hidup bangsa Indonesia. Proklamasi merupakan Pernyataan Kemerdekaan "Declaration of Independence" dari rakyat Indonesia. Pernyataan Kemerdekaan atau Proklamasi Kemerdekaan ini merupakan sumber hukum dari adanya Republik Indonesia. Jadi Proklamasi Kemerdekaan itu menupakan sandaran hukum berdirinya negara Republik Indonesia. Proklamasi Kemerdekaan yang

${ }^{6}$ Lihat dalam Ni'matul Huda, Hukum Tata Negara Kajian Teoritis dan Yuridis Terhadap Konstitusi Indonesia, (Pusat Studi Hukum FHUll kerjasama dengan Gama Media, Yogyakarta, 1999), hlm. 40.

${ }^{7}$ ASS. Tambunan, Amandemen Kebablasan Undang-Undang Dasar Baru dan Komisi Konstitusi, (Biro Hukam dan Hukum DPR Rl, Jakarta, 2002), him. 16. 
merupakan Pernyataan Kemerdekaan bangsa Indonesia itu dimuat dalam alinea ketiga Pembukaan UUD 1945. Maka dari itu, sudah terang bahwa Proklamasi Kemerdekaan yang merupakan sumber hukum berdirinya negara Republik Indonesia tidak dapat dipisahkan dari Pembukaan UUD 1945. Pembukaan UUD 1945 jelas merupakan penuangan daripada cita-cita bangsa Indonesia. ${ }^{8}$

Di dalam Penjelasan UUD 1945 dapat diketahui bahwa Pembukaan UUD 1945 mengandung empat pokok-pokok pikiran yang meliputi suasana kebatinan dari UUD Negara Republik Indonesia. Pokok-pokok pikiran ini merupakan cita-cita hukum bangsa Indonesia yang mendasari hukum dasar negara, baik yang tertulis maupun yang tidak tertulis. Pokok-pokok pikiran tersebut adalah sebagai berikut:

Pokok pikiran pertama: "Negara" begitu bunyinya - "melindungi segenap bangsa Indonesia dan seluruh tumpah darah Indonesia dengan berdasar atas persatuan dengan mewujudkan keadilan sosial bagi seluruh rakyat Indonesia." Dalam pembukaan ini diterima aliran pengertian negara persatuan, negara yang melindungi dan meliputi segenap bangsa Indonesia seluruhnya. Jadi negara mengatasi segala paham golongan, mengatasi segala paham perseorangan, Negara menurut pengertian "pembukaan" itu menghendaki persatuan meliputi segenap bangsa Indonesia seluruhnya. Inilah suatu dasar negara yang tidak boleh dilupakan. Rumusan ini menunjukkan pokok pikiran Persatuan. Dengan pengertian yang lazim, negara, penyelenggara negara dan setiap warga negara wajib mengutamakan kepentingan negara di atas kepentingan golongan ataupun perorangan.

Pokok pikiran kedua:"Negara hendak mewujudkan keadilan sosial bagi seluruh rakyat". Ini merupakan pokok pikiran Keadilan sosial, yang didasarkan pada kesadaran bahwa manusia Indonesia mempunyai hak dan kewajiban yang sama untuk menciptakan keadilan sosial dalam kehidupan masyarakat.

Pokok pikiran ketiga yang terkandung dalam "pembukaan" ialah negara yang berkedaulatan rakyat, berdasarkan atas kerakyatan dan permusyawaratan perwakilan. Oleh karena itu sistem negara yang terbentuk dalam Undang-Undang Dasar harus berdasar atas kedaulatan rakyat dan berdasar atas permusyawaratan perwakilan. Memang aliran ini sesuai dengan sifat masyarakat Indonesia. Pokok pikiran yang ketiga ini menunjukkan bahwa di dalam negara indonesia yang berdaulat adalah rakyat Indonesia, kedaulatan ada di tangan rakyat. Dan pelaksanaan dari asas kedulatan ini disertai asas lainnya yaitu asas musyawarah dan dilakukan oleh wakilwakil rakyat. Jadi pelaksanaan asas kedaulatan ini dengan musyawarah yang dilakukan wakil-wakil rakyat.

Pokok pikiran keempat yang terkandung "pembukaan" ialah negara berdasar atas Ketuhanan Yang Maha Esa menurut dasar kemanusiaan yang adil dan beradab. Oleh karena itu, Undang-Undang Dasar harus mengandung isi yang mewajibkan pemerintah dan lain-lain penyelenggara negara untuk memelihara budi pekerti kemanusiaan yang luhur dan memegang teguh cita-cita moral rakyat yang luhur. Pokok pikiran yang keempat ini menunjukkan keyakinan bangsa Indonesia

${ }^{8}$ Azhary, Pancasila dan UUD 1945, (Ghalia Indonesia, Jakarta, 1985), hlm. 14-15. 
akan adanya Tuhan Yang Maha Esa, adanya cita kemanusiaan dan cita keadilan dari bangsa Indonesia yang menjunjung tinggi harkat dan martabat manusia dan kesemuanya itu menjadi dasar negara yang mengikat baik pemerintah maupun rakyatnya.

Keempat pokok pikiran tersebut jelas merupakan pancaran dari pandangan hidup dan dasar falsafah negara Pancasila. Dengan mengungkap keempat pokok pikirn ini dapatlah kita gambarkan bahwa Pembukaan UUD 1945 itu mengandung pandangan hidup bangsa Indonesia Pancasila. ${ }^{9}$

Pada tanggal 15 Juli 1945, Ir. Soekarno sebagai penggali Pancasila dalam pidatonya di depan BPUPKI menyatakan: "Keberanian menunjukkan bahwa kita tidak hanya membebek kepada contoh-contoh UUD negara lain. Akan tetapi, membuat sendiri UUD yang baru, yang berisi kefahaman keadilan yang menentang individualisme dan liberalisme, yang berjiwa kekeluargaan dan gotong-royong." ${ }^{10}$

Selain keempat pokok pikiran itu, keempat alinea Pembukaan Undang-Undang Dasar masing-masing mengandung pula citacita luhur dan filosofis yang harus menjiwai keseluruhan sistem berpikir materi UndangUndang Dasar. Alinea pertama menegaskan keyakinan bangsa Indonesia bahwa kemerdekaan itu adalah hak asasi segala bangsa, dan karena itu segala bentuk penjajahan di atas dunia harus dihapuskan, karena tidak sesuai dengan peri kemanusiaan dan peri keadilan. Alinea kedua menggambarkan proses perjuangan bangsa Indonesia yang panjang dan penuh penderitaan yang akhirnya berhasil mengantarkan bangsa Indonesia ke dapan pintu gerbang negara Indonesia yang merdeka, bersatu, berdaulat, adil dan makmur. Alinea ketiga menegaskan pengakuan bangsa Indonesia akan ke-Maha Kuasaan Tuhan Yang Maha Esa, yang memberikan dorongan spiritual kepada segenap bangsa untuk memperjuangkan perwujudan cita-cita luhurnya, yang atas dasar keyakinan spiritual serta dorongan luhur itulah rakyat Indonesia menyatakan kemerdekaannya.

Alinea keempat menggambarkan visi bangsa Indonesia mengenai bangunan kenegaraan yang hendak dibentuk dan diselenggarakan dalam rangka melembagakan keseluruhan cita-cita bangsa untuk merdeka, bersatu, berdaulat, adil dan makmur dalam wadah Negara Indonesia. Alinea keempat ini menentukan dengan jelas mengenai Tujuan Negara dan Dasar Negara Indonesia sebagai Negara yang menganut prinsip demokrasi konstitusional. Negara Indonesia itu dimaksudkan untuk tujuan (1) melindungi segenap bangsa Indonesia dan seluruh tumpah darah Indonesia; (2) memajukan kesejahteraan umum; (3) mencerdaskan kehidupan bangsa; dan (4) mewujudkan ketertiban dunia berdasarkan kemerdekaan,

\footnotetext{
${ }^{9}$ Ibid., hlm. 20-21.

${ }^{10}$ Untuk pertama kalinya Pancasila diucapkan oleh ir. Soekarno dalam pidato tanggal 1 Juni 1945 yang kemudian dikenal sebagai "lahirnya Pancasila". Tanggal 15 Juli 1945, Dr. Radjiman Wediodiningrat, Ketua BPUPKI meminta agar Ir Soekarno membentangkan kembali Pancasila sebagai filosofische grondslag, filsafat, dasar pikiran, jwa dan hasrat yang sedalam-dalamnya dari bangsa Indonesia yang hendakmendirikan negara Indonesia yang merdeka yang sekaligus merupakan penjelasan dan pembelaan atas kritik-kritikyang disampaikan pada rapat tanggal 14 Juli 1945.
} 
perdamaian abadi dan keadilan sosial. Memajukan kesejahteraan umum dan mencerdaskan kehidupan bangsa merupakan dua tujuan positif sebagai "common virtues" atau "amr al ma'ru" yang perlu diwujudkan bersama melalui pelembagaan Negara Indonesia itu. Sedangkan tujuan yang hendak dicapai dengan peran negara dalam rangka perlindungan internal dan ketertiban dunia eksternal, bersifat negatif dalam rangka "nahi al-munkar" terhadap segala bentuk ancaman dan tantangan yang perlu dicegah dan ditanggulangi atau dihadapi dengan sebaikbaiknya berdasarkan prinsip kemerdekaan, perdamaian abadi dan keadilan sosial."

Pokok-pokok pikiran tersebut mencakup suasana kebatinan yang terkandung dalam Undang-undang Dasar. Pokok-pokok pikiran itu mencerminkan falsafah hidup (weltanshaung) dan pandangan dunia (world view) bangsa indonesia serta cita-cita hukum (rechtsidee) ${ }^{12}$ yang menguasai dan menjiwai hukum dasar, baik yang tertulis (Undang-Undang Dasar) maupun yang tidak tertulis. Undang-Undang Dasar mewujudkan pokok-pokok pikiran itu dalam perumusan pasal-pasalnya yang secara umum mencakup prinsip-prinsip pemikiran dalam garis besarnya.

\section{Cita Hukum (Rechtsidee) Pancasila}

Dalam upaya lebih memahami tentang
Rechtsidee atau cita hukum, Koesnoe menyatakan hawa cita hukum itu merupakan nilai hukum yang telah diramu dalam kesatuan dengan nilai-nilai lainnya yang berasal dari kategori nilai-nilai lainnya, yang menunjukkan pula sejauhmana fenomena kekuasaan terintegrasi padanya. Cita hukum itu meliputi segi formalnya yaitu sebagai suatu wadah nilainilai hukum yang telah digarap dengan memperhitungkan alam kenyataan sekeliling kelompok yang bersangkutan. Segi materiil atau substansial cita hukum adalah sebagai nilai hukum yang telah diramu dalam satu kesatuan dengan nilai-nilai dari kategori nilai lainnya termasuk fenomena kekuasaan, menurut cita rasa budaya masyarakat yang bersangkutan. ${ }^{13}$

Cita hukum itu terbentuk dalam pikiran dan sanubari manusia sebagai produk berpadunya pandangan hidup, keyakinan keagamaan dan kenyataan kemasyarakatan yang diproyeksikan pada proses pengkaidahan perilaku warga masyarakat yang mewujudkan tiga unsur : keadilan, kehasil-gunaan (doelmatigheid) dan kepastian hukum. Dalam dinamika kehidupan kemasyarakatan, cita hukum itu akan mempengaruhi dan berfungsi sebagai asas umum yang mempedomani (guiding principle), norma kritik (kaidah evaluasi) dan faktor yang memotivasi dalam penyelenggaraan hukum (pembentukan, penemuan, penerapan hukum) dan perilaku

\footnotetext{
"Jimly Asshiddiqie, Konstitusidan Konstitusionalisme Indonesia, diterbitkan atas kerjasama (Mahkamah konstitusi dengan Pusat Studi HTN FH-UI, Jakarta, 2004), hlm. 52-53.

${ }^{12}$ Cita hukum (rechtsidee) mengandung arti bahwa pada hakikatnya hukum sebagai aturan tingkah laku masyarakat berakar pada gagasan, rasa, karsa, cipta dan fikiran dari masyarakat itu sendiri." Jadi, cita hukum itu adalah gagasan, karsa, cipta dan pikiran berkenaan dengan hukum atau persepsi tentang makna hukum, yang dalam intinya terdiri atas tiga unsur: keadilan, kehasil-gunaan (doelmatigheid) dan kepastian hukum. Lihat dalam B. Arief Sidharta, Refleksi Tentang Strukiur Ilmu Hukum, (Mandar Maju, Bandung, 1999), hlm. 181.

${ }^{13}$ Majalah Pembinaan Hukum Nasional, No. 1, 1995, hlm. 73.
} 
hukum.

Dirumuskan dan dipahaminya cita hukum akan memudahkan penjabarannya ke dalam berbagai perangkat aturan kewenangan dan aturan perilaku dan memudahkan terjaganya konsistensi dalam penyelenggaraan hukum. Dengan demikian, seyogianya tata hukum itu merupakan sebuah eksemplar rasifikasi cita hukum ke dalam berbagai kaidah hukum yang tersusun dalam sebuah sistem. ${ }^{14}$

Menurut Radbruch, rechtsidee merupakan bagian kebudayaan yang berhubungan dengan nilai keadilan. Pendapat ini berbeda dengan Kelsen yang menyatakan bahwa konsep-konsep ideologi, moral, termasuk pula keadilan, adalah berada di luar hukum, dan mempunyai pemahaman yang berbeda. Kelsen menyatakan Law and justice are two different concepts: Kelsen juga mengatakan bahwa Rechtsidee itu mempunyai dua fungsi, yaitu fungsi regulatif dan fungsi konstitutif. ${ }^{15}$ Menurut Stammler, Rechtsidee mengandung pengertian sebagai arah pikiran (denkrichting) atau metode pikiran (denkmethode), yang digambarkan sebagai kehendak sosial. Dalam hal ini, menurut Stammler, bahwa arah dari cita-cita masyarakat itulah yang menjadi ide hukum atau rechtsidee ini menentukan isi hukum positit: ${ }^{6}$

Dalam pandangan Larenz, rechtsidee itu mendapatkan pernyataannya di dalam asasasas hukum. Dengan rumusan yang dibalik Larenz menyatakan rechtsbeginselen als uitingen van de rechtsidee. Lebih lanjut Larenz menyatakan bahwa rechtsidee bersifat normatif, apriori konstitutif sebagai syarat transendental yang mendasari setiap bentuk hukum positif. ${ }^{17}$

Cita hukum bangsa Indonesia berakar dalam Pancasila yang oleh para Bapak Pendiri Negara Republik Indonesia ditetapkan sebagai landasan kefilsafatan dalam menata kerangka dan struktur dasar organisasi negara sebagaimana yang dirumuskan dalam UUD 1945. Pancasila adalah pandangan hidup bangsa Indonesia yang mengungkapkan pandangan bangsa Indonesia tentang hubungan antara manusia dan Tuhan, manusia dan sesama manusia, serta manusia dan alam semesta yang berintikan keyakinan tentang tempat manusia individual di dalam masyarakat dan alam semesta. Dangan kata lain, Pancasila adalah jawaban bangsa Indonesia terhadap pertanyaan "Was ist der Mensch, und was ist seine Stellung im Sein? Yang merupakan inti keseluruhan pemikiran kefilsafatan Max Scheler. Jawaban tersebut secara formal dicantumkan dalam Pembukaan UUD 1945, khususnya dalam rumusan lima dasar kefilsafatan bernegara, dan dijabarkan lebih lanjut dalam pasal-pasal Batang Tubuh Undang-Undang Dasar tersebut. Dengan demkian, cita hukum Pancasila harus mencerminkan tujuan bernegara dan seperangkat nilai dasar yang tercantum baik dalam Pembukaan maupun batang tubuh serta Penjelasan UUD 1945, dan berbagai ketetapan MPR terkait. ${ }^{18}$

\footnotetext{
${ }^{14}$ B. Arief Sidharta, Ibid.

${ }^{15}$ Soejadi, Pancasila..., Op.Cit., him. 77.

${ }^{16} \mathrm{Ibid}$.

${ }^{17} \mathrm{lbid}$., hlm. 78.
}

${ }^{18}$ B. Arief Sidharta, Refleksi..., Op.Cit., Hlm. 182. Untuk kondisi indonesia sekarang (pasca amandemen UUD 1945), cita hukum Pancasila tercermin dalam Pembukaan dan pasal-pasal, karena Penjelasan UUD 1945 


\section{Kaitan antara Pembukaan dengan Batang Tubuh}

Pada umumnya konstitusi suatu negara mempunyai pembukaan yang menjadi pernyataan isi sebuah pembukaan dan kedudukannya terhadap (batang tubuh) undang-undang dasar. Pada umumnya isi suatu undang-undang dasar berkenaan dengan alasan, maksud dan tujuan berdirinya suatu negara. Bahkan kadang-kadang dalam suatu pembukaan itu dikemukakan sejarah perjuangan suatu bangsa yang kemudian berhasil mendirikan suatu negara. Oleh karena itu substansi Pembukaan UUD 1945 merupakan perjanjian luhur wakil-wakil rakyat Indonesia.

Pembukaan UUD 1945 sarat dengan gagasan vital-filsafati yang mengandung muatan nilai-nilai etis dan moral, nilai-nilai politis-ideologis, dan nilai-nilai yuridis yang merupakan satu kesatuan integral-integratif, yang seharusnya kita jadikan paradigma imperatif - dan bukan lagi sebagai alternatif di dalam kita melakukan pengkajian pasalpasal UUD 1945. Suatu paradigma dengan visi jauh ke depan dengan komitmen transenden sebagai perekat persatuan dan kesatuan dalam hidup berbangsa dan bernegara. ${ }^{19}$

Pada bentuk umumnya Undang-Undang Dasar itu terdiri atas dua bagian, yaitu Pembukaan dan Batang Tubuh UndangUndang Dasar. Keduanya itu dimuat dalam satu naskah. Untuk mengetahui betapa eratnya hubungan antara Pembukaan dan
Batang Tubuh UUD 1945, dapat kita baca dari penjelasan resmi UUD 1945 yang berbunyi: "Pokok-pokok pikiran tersebut meliputi suasana kebatinan dari Undang-Undang Dasar Negara Indonesia. Pokok pikiran ini mewujudkan cita-cita hukum (rechts idee) yang menguasai Hukum Dasar Negara, baik hukum yang tertulis (UUD) maupun hukum yang tidak tertulis UUD menciptakan pokok-pokok pikiran ini dalam pasalnya."

Daripenjelasan tersebut dapat dilihat bahwa Batang Tubuh UUD 1945 yang terdiri dari pasalpasal adalah merupakan perwujudan, perincian daripada pokok-pokok pikiran yang terkandung dalam Pembukaannya. Jadi pokok-pokok pikiran yang terkandung dalam Pembukaan UUD Negara yang merupakan suașana kebatinan dari Undang-Undang Dasar serta mewujudkan cita-cita hukum yang menguasai Hukum Dasar Negara. Dengan demikian dapatlah dikatakan bahwa pook-pokok pikiran yang terkandung dalam Pembukaan UUD Negara menjiwai batang tubuh UUD Negara (pasal-pasalnya) merupakan realisasi, perwujudan atau perincian daripada pokokpokok pikiran tadi (yang terkandung dalam Pembukaan). Sedangkan Pembukaan itu sendiri dijiwai oleh dasar falsafah Pancasila.

Dengan tetap menyadari keagungan nilai-nilai yang terkandung dalam Pancasila dan dengan memperhatikan hubungan antara Pembukaan dengan Batang Tubuh UUD sendiri, maka dapatlah disimpulkan bahwa Pembukaan UUD yang memuat dasar falsafah

sudah dihapuskan, demikian pula dengan Ketetapan MPR.

${ }^{19}$ Koento Wibisono S., "Garis Besar Uraian tentang Kaitan Pembukaan UUD 1945 dengan Konstitusi", Makalah seminar Kajian Komprehensif tentang Perubahan UUD Negara RI Tahun 1945kerjasama Sekretariat Jenderal MPR RI dengan FH UGM, Yogyakarta, 10 Desember 2003. 
Negara Pancasila dan UUD 1945 adalah satu kesatuan yang tidak dapat dipisahkan; bahkan merupakan rangkaian kesatuan nilai dan norma yang terpadu. UUD 1945 terdiri dari rangkaian pasal-pasal yang merupakan perwujudan dari pokok-pokok pikiran yang terkandung dalam Pembukaan UUD, yang tidak lain adalah pokok-pokok pikiran, yaitu: Persatuan Indonesia, Keadilan Sosial, Kedaulatan Rakyat berdasar atas kerakyatan dan permusyawaratan perwakilan dan Ketuhanan Yang Maha Esa menurut kemanusiaan yang adil dan beradab, yang tidak lain adalah sila-sila dari Pancasila; sedangkan Pancasila itu sendiri memancarkan nilai-nilai yang luhur yang telah mampu memberikan semangat kepada dan terpancang dengan khidmat dalam perangkat UUD 1945. Pembukaan dan Batang Tubuh (pasal-pasal UUD 1945), UUD 1945 pada hakikatnya merupakan satu rangkaian kesatuan yang tidak dapat dipisahkan. ${ }^{20}$

\section{Hasil Kajian Komisi Konstitusi}

MPR Rl periode 1999-2004 telah bersepakat untuk mempertahankan Pembukaan UUD 1945. Kesepakatan tersebut tidaklah dapat diartikan sebagai sikap untuk mensakralkan pembukaan. Kesepakatan untuk tetap mempertahankan Pembukaan UUD 1945 dilandasi oleh berbagai alasan. Alasan-alasan tersebut antara lain adalah bahwa Pembukaan merupakan suatu cita hukum (rechtsidee), dan sekaligus norma fundamental negara (Staatsfundamentalnorm) yang merupakan pedoman bagi pembentukan hukum di bawahnya. Selain itu Pembukaan mengandung nilai-nilai universal tentang kebenaran dan keadilan.

Kesepakatan MPR untuk mempertahankan Pembukaan bukan sekedar didukung oleh kesepakatan nasional, namun mendapatkan pembenaran dari hal-hal sebagai berikut: ${ }^{21}$

\section{Nilai dan Norma Dasar Negara (Staatsfundamentalnorm)}

Upaya mempertahankan Pembukaan UUD 1945 sesungguhnya terkait dengan peristiwa penting Proklamasi Kemerdekaan 17 Agustus 1945 sebagai perjanjian luhur (Gentlement Agreement). Peristiwa sejarah bagi bangsa Indonesia yang amat penting bagi upaya memperjuangkan suatu kemerdekaan. Kemerdekaan merupakan pintu gerbang keberadaan Republik Indonesia sebagai negara berdaulat. Lebih dari itu, wujud konkrit Proklamasi secara historis terkait dengan Piagam Djakarta. Presiden Soekarno mengakui akan suasana kebatinan Pembukaan yang telah memberikan semangat zaman (volkgeist) yang dapat menjadi pengarah bagi penyelenggara negara.

Mempertahankan Pembukaan dapat berarti bahwa bangsa Indonesia menghormati dan mengabadikan semangat perjuangan pendiri bangsa atas kelangsungan sejarah dan kemerdekaan Indonesia. Mengabadikan nilainilai terpuji bangsa juga dapat menjadi tali batin masyarakat indonesia untuk memelihara persatuan dan kesatuan. Pembukaan sebagai dasar negara harus menjamin tegaknya Bhineka Tunggal Ika, secara moral menjadi

${ }^{20}$ Azhary, Pancasila..., Op.Cit., hlm. 22.

${ }^{21}$ Hasil Kerja Komisi Konstitusi yang dibukukan oleh Krisna Harahap dalam Konstitusi Republik Indonesia Sejak Proklamasi Hingga Reformasi, (Grafiti Budi Utami, Bandung, 2004), hlm.189-195. 
kewajiban untuk mempertahankannya, mematuhi dan menghormati esensi perjajian luhur tersebut.

\section{Visi dan Misi Negara}

Kehendak untuk tidak melakukan perubahan terhadap Pembukaan sesungguhnya dikaitkan dengan dasar dan tujuan berdirinya Negara Kesatuan Republik Indonesia. Visi dan misi bangsa (Grand Vision and Mission of State) mengandung cita-cita luhur dan mulia yang jauh ke depan (Grand Vision). Hal ini harus menjadi tekat bulat suatu bangsa dan masyarakatnya dalam mewujudkan tujuan negara, baik yang tercakup dalam pencapaian tujuan jurisdiksi nasional maupun dalam dimensi internasional. Pencapaian tujuan negara dalam jurisdiksi nasional tidak saja terbatas pada adanya pembagian dan pemisahan antara kekuasaan legislatif, eksekutif dan judikatif. Akan tetapi hendaknya dapat diarahkan pada upayaupaya konkrit untuk melindungi dan mensejahterakan segenap warga negara.

Pencapaian tujuan negara dalam dimensi internasional tertuang dalam sikap suatu negara atau bangsa untuk mematuhi ketentuan hukum internasional, yaitu ikut aktif dalam upaya-upaya penyelenggaraan tatanan dunia yang tertib (world order) dan perdamaian dunia (world peace). Bagaimana tindakan negara selalu peduli dengan cara-cara damai dalam menyelesaikan suatu pertikaian, termasuk menempatkan hukum sebagai panglima (supremacy of law) merupakan visi dan misi negara.

\section{Dasar dan Filsafat Negara (Filosofische Grondslag)}

Pentingnya Pembukaan UUD 1945 tetap dipertahankan terkait dengan eksistensi dasar filosofis atau ideologi negara. Sebab,
Pembukaan merupakan kerangka acuan dan sumber pemersatu bangsa, yang dihasilkan melalui perjuangan politik dan diwujudkan dalam suatu kesepakatan nasional (National Consensus). Pancasila sebagai dasar filsafat kenegaraan berfungsi sebagai pengarah dan pemelihara komitmen kebersamaan, dan persatuan masyarakat indonesia.

Pancasila sebagai acuan dasar dalam bermasyarakat, berbangsa dan bernegara, di dalamnya terkandung dimensi Teologis yang menempatkan eksistensi Tuhan Yang Maha Esa sebagai Sang Pencipta. Sila Pertama yaitu "Ketuhanan Yang Maha Esa", menjadi șumber inspirasi bagi Sila Persatuan, Kemanusiaan, Kerakyatan, dan Keadilan. Dasar-dasar filosofis kehidupan bernegara diletakkan sebagai kekuatan potensi akal manusia secara kolektif. Karena itu, isi Pembukaan yang mengandung Pancasila sebagai dasar negara menempatkan warga negara Indonesia sebagai makhluk monodualis. Hal itu merupakan suatu pemikiran yang menempatkan manusia sebagai makhluk Tuhan, sekaligus makhluk sosial. Atas dasar filosofis seperti itu, masyarakat Indonesia menolak ajaran manusia sebagai zoon politicon atau homo economicus semata, melainkan suatu masyarakat yang juga mengakui akan kekuatan Tuhan Yang Maha Esa sebagai pencipta. Menempatkan Pancasila sebagai dasar negara dalam Pembukaan secara tegas menolak timbulnya paham Indonesia sebagai negara agama (theocracy), dan tidak pula dapat memisahkan secara tegas adanya pemisahan agama dengan negara (secularisme).

\section{Cita Hukum (Rechtsidee)}

Pembukaan mengandung cita hukum dan merupakan hukum tertinggi (supreme of law of 
the land) yang tidak saja mengandung prinsipprinsip atau asas-asas hukum fundamental, norma-norma dasar yang berfungsi sebagai sumber hukum tertinggi dan harus menjadi acuan juridis bagi ketentuan hukum yang secara hierarkis berada di bawah undang-undang dasar.

Pembukaan sebagai cita hukum harus dapat mengarahkan pada terciptanya normanorma dasar yang mengandung kepastian hukum (legal certainty), kemanfaatan (utility) dan keadilan bagi semua (justice for all). Ketiga prinsip dasar yuridis tersebut menjadi sangat penting. Secara yuridis dan idiologis Pembukaan berfungsi sebagai instrumen pengarah dan pengendali tegaknya pertindungan HAM, status, fungsi dan kewenangan negara, mekanisme hubungan antara lembaga negara sesamanya dan hubungan antara negara dengan warga negaranya.

Pembukaan sebagai rechtsidee atau cita hukum akan tetap menjadi supreme of law of the nation, pengarah dan penentu kepastian peraturan hukum bilamana masyarakat mengakui keberadaannya dengan menempatkan hukum dasar tertulis dan hukum dasar tidak tertulis yang berfungsi sebagai panglima dalam menyelesaikan pertikaian yang tejjadi dalam masyarakat dan bangsa.

\section{Simpulan}

Dapat atau tidaknya Pembukaan UUD 1945 diubah oleh MPR bukan hanya karena alasan adanya kesepakatan politik dari seluruh anggota MPR untuk tidak merubahnya, tetapi juga dikarenakan Pembukaan mengandung cita hukum (rechtsidee) dan merupakan hukum tertinggi (supreme of law of the land) yang tidak saja mengandung prinsip-prinsip atau asasasas hukum fundamental, norma-norma dasar yang berfungsi sebagai sumber hukum tertinggi dan harus menjadi acuan juridis bagi ketentuan hukum yang secara hierarkis berada di bawah undang-undang dasar.

\section{Daftar Pustaka}

ASS. Tambunan, Amandemen Kebablasan Undang-Undang Dasar Baru dan Komisi Konstitusi, Biro Hukam dan Hukum DPR RI, Jakarta, 2002.

Azhary, Pancasila dan UUD 1945, Ghalia Indonesia, Jakarta, 1985.

Bagir Manan, Teori dan Politik Konstitusi, FH UIl Press, Yogyakarta; 2003. DPR, DPD dan MPR dalam UUD 1945 BARU, FH UII Press, Yogyakarta, 2003.

\section{B. Arief Sidharta, Refleksi Tentang Struktur Ilmu} Hukum, Mandar Maju, Bandung, 1999.

Jimly Asshiddigie, Format Kelembagaan Negara dan Pergeseran Kekuasaan Dalam UUD 1945, FH Uil Press, Yogyakarta, 2003.

Dahlan Thaib, Jazim Hamidi dan Ni'matul Huda, Teori dan Hukum Konstitusi, Cetakan Ketiga, Rajawali Press, Jakarta, 2003.

Jimly Asshiddiqie, "Konsolidasi Materi UUD RI", makalah dalam kuliah perdana Program Magister (S2) IImu Hukum Universitas Islam Indonesia, Yogyakarta, 13 September 2001.

, Konstitusi dan Konstitusionalisme indonesia, diterbitkan atas kerjasama Mahkamah konstitusi dengan Pusat Studi HTN FH-UI, Jakarta, 2004.

Koento Wibisono S., Garis Besar Uraian 
tentang Kaitan Pembukaan UUD 1945 dengan Konstitusi, Makalah Seminar "Kajian Komprehensif tentang Perubahan UUD Negara RI Tahun 1945 Kerjasama Sekretariat Jenderal MPR RI dengan FH UGM", Yogyakarta, 10 Desember 2003.

Krisna Harahap dalam Konstitusi Republik Indonesia Sejak Proklamasi Hingga Reformasi, Grafiti Budi Utami,. Bandung, 2004.

Moh. Tolchah Mansoer, Teks Resmi Dan Beberapa Soal Tentang UUD 1945, Alumni, Bandung, 1983.

Ni'matul Huda, Hukum Tata Negara Kajian
Teoritis dan Yuridis terhadap Konstitusi - Indonesia, Pusat Studi Hukum FH Ull, Yogyakarta, 1999.

, Politik Ketatanegaraan Indonesia Kajian terhadap Dinamika Perubahan UUD 1945, FH UII Press, Yogyakarta, 2003.

Soejadi, Pancasila Sebagai Sumber Tertib Hukum Indonesia, Lukman Offset, Yogyakarta, 1999.

Sri Soemantri M, Prosedur dan Sistem Perubahan Konstitusi, Alumni, Bandung, 1987.

UUD Negara Republik Indonesia Tahun 1945 dan Perubahannya. 